
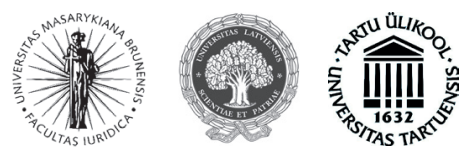

ISSN 1392-6195 (print) ISSN 2029-2058 (online) JURISPRUDENCIJA JURISPRUDENCE 2013, 20(3), p. 1005-1022.

\title{
EUROPOS ADMINISTRACINĖS TEISĖS SAMPRATA IR ES ADMINISTRACINIŲ PROCEDÜRŲ RINKINIO RENGIMO PRIELAIDOS
}

\author{
Ieva Deviatnikovaite \\ Mykolo Romerio universiteto Teisès fakulteto \\ Konstitucinès ir administracinès teisès institutas \\ Ateities g. 20, LT-08303 Vilnius, Lietuva \\ Telefonas (+370 5) 2714546 \\ Elektroninis paštas ieva@mruni.eu
}

Pateikta 2013 m. rugpjūčio 15 d., parengta spausdinti 2013 m. rugpjūčio 28 d.

doi:10.13165/JUR-13-20-3-08

\begin{abstract}
„Europos administracinè teise, nors dažnokai nevisiškai suprantama, vystosi bei tampa svarbiu veiksniu, formuojančiu politikos igyvendinimo realybe Europos Sajungoje."1
\end{abstract}

Anotacija. Esama keletas priežasčiu, dèl kuriu verta studijuoti Europos administracine teise. Pirma, tai jaunas mokslas. Antra, Europos administracine teise paprastai traktuojama iš skirtingu valstybiu skirtingu teises tradiciju poziciju, todèl bet kokios pastangos unifikuoti požiüri i ją gali sukurti pagrinda vienodam Europos administracinès teisés modeliui. Trečia, Lietuvoje nèra darbu, analizuojanciu Europos administracine teisę.

Administracines teisès specialistai, bandydami apibrèžti Europos administracine teisę, pateikia nemažai skirtingu požiūriu i šia teisę, pavyzdžiui, Europos administracinè teisé strictu sensu ir administracinès teisès europeizacija. Teigiama, jog išsamiausia Europos

1 Herwig, C. H.; Hofmann, C. H. Seven Challenges for EU Administrative Law. Europa Law Publishing. 2009, 2 (2): 37. 
administracines teises vaizdini atskleidžia trys Europos administracines teises sampratos. Pirmoji samprata Europos administracinę teise apibüdina kaip Europos Sajungos (toliau ES) administracine teise, kurios galiojimo ribas galima nustatyti remiantis trimis aspektais - funkciniu, instituciniu ir procedüriniu. Antroji - kaip bendros administracijos erdves teise arba kaip administracijos bendradarbiavimo teisę. Trečioji samprata leidžia Europos administracinę teisę suvokti kaip teisę, bendrą Europos valstybiu viešajai administracijai tiek pagrindiniu squoku, tiek pagrindiniu teises principu bei baziniu institutu prasmemis - ius commune. Šie trys požiüriai bei ES administraciniu procedüru rinkinio, kaip priemonès, padedančios vystyti ES administracinę teise, analize ir yra straipsnio tyrimo objektas.

Reikšminiai žodžiai: Europos administracinè teisè, ES administracinè teisè, administracinio bendradarbiavimo teise, ius commune, ES administracinès procedüros.

\section{Itvadas}

Temos aktualumas: teigiama², kad egzistuoja keletas priežasčių, dèl kurių verta studijuoti Europos administracinę teisę. Pirma, ši teisè yra teisinių tyrimų, prasidèjusių Vakarų Europoje praeito šimtmečio antroje pusejje, rezultatas. Taigi - tai gana jaunas mokslas: pirmieji du J. Schwarze'o knygos „Europäisches Verwaltungsrecht“ tomai buvo išspausdinti 1988 metais. Vèliau jie buvo perleisti anglų kalba „European Administrative Law“ (1992) ir prancūzų kalba „Droit Administratif Européen“ (1994). Manoma, kad tuomet Europos administracinè teise ịsitvirtino kaip teisès šaka ${ }^{3}$. Antra, Europos administracinès teisės pagrindų užuomazgų galima rasti skirtingų valstybių administracinèse teisinèse sistemose, todèl ją traktuoti, unifikuotai aiškinti yra sudètinga užduotis, nes paprastai tai daroma iš skirtingų valstybių teisės tradicijų pozicijų. Galbūt šios pastangos ilgainiui padès pagrindą sukurti vieną Europos administracinès teisès modelị. Pagaliau, autorès nuomone, yra ir trečioji priežastis - Lietuvoje nèra darbų, tiriančių Europos administracinès teisès fenomeną ${ }^{4}$.

Administracinès teisès specialistai ${ }^{5}$, bandydami apibrèžti Europos administracinę teisę, paprastai skiria tris skirtingas Europos administracinès teisès sampratas. Jas sujungus ị vieną, ,atsiskleidžia visas Europos administracinès teisès vaizdinys" “6. Pirmoji samprata Europos administracinę teisę charakterizuoja kaip ES administracinę teisę. Antroji - kaip bendros administracijos erdvès teisę, arba kaip administracijos bendradarbiavimo teisę, t. y. teisę, naudojamą skirtingais tarpvyriausybiniais ar tarpvalstybiniais bei nevyriausybiniais lygmenimis. Trečioji samprata leidžia Europos administracinę

2 Hendrych, D., et al. Správní právo. Obecná část. Praha: Nakladatelství C. H. Beck, 2012, p. 702.

3 Schwarze, J. European Administrative Law. London: Sweet \& Maxwell, 2010, p. cix.

4 Išskyrus darbus, analizuojančius ES teisès ịgyvendinimo problematiką Lietuvos administracinèje teisėje. Pavyzdžiui, Valančius, V.; Kavalnè, S. Europos Sajungos teisès igyvendinimas Lietuvos administracinejje teisèje. Vilnius: Registrų centras, 2009.

5 Pomahač, R.; Handrlica, J. Evropské správní právo. Praha: Nakladatelství C. H. Beck, 2012, p. 15-19.

6 Hendrych, D., et al., op. cit., p. 713. 
teisę suvokti kaip teisę, bendrą valstybių narių viešajai administracijai tiek pagrindinių sąvokų, tiek pagrindinių teisès principų bei bazinių institutų prasmėmis - ius commune. Teigiama, kad šių Europos administracinès teisès sampratų atsiradimą lèmè svarstymai apie daugiadimensinę administracinę erdvę

Tačiau egzistuoja ne tik minètasis požiūris ị Europos administracinę teisę. Pavyzdžiui, J. Schwarze’as savo monografijoje „Europäisches Verwaltungsrecht“ Europos administracinę teisę skiria stricto $s e n s u^{8}$ požiūriu. Čia teigiama, kad ši teisè yra teisẻkūros procesų, kuriuos atlieka ES institucijos ir agentūros bei valstybių narių institucijos ES ribose, rezultatas. Taip pat egzistuoja administracinės teisės europeizacijos samprata $^{9}$ - Europos administracinè teisè apibūdinama kaip teisè, turinti nacionalinę kilmę ir pritaikyta ES teisės igyvendinimo poreikiams, arba kaip procesas, kuriuo Europos administracinė teisè ,tampa geriau žinoma valstybių narių teismams ir labiau jų panaudojama $^{\text {"10 }}$. Kai kurie mokslininkai ${ }^{11}$ į Europos administracinę teisę žvelgia ir kiek kitais aspektais. Jie teigia, kad Europos administracinė teisė yra susijusi su ES teisès igyvendinimu ir taikymu plačiaja prasme, t. y. ES teisės igyvendinimo ir taikymo pagrindinis instrumentas yra institucijų ir administravimo subjektų bendradarbiavimas Sąjungos bei nacionaliniu lygmeniu (angl. shared government ${ }^{12}$ ). Viena vertus, čia svarbūs tokie teisiniai instrumentai kaip direktyvos, reglamentai, taip pat ES Teisingumo Teismo praktika. Antra vertus, Europos administracinė teisè yra susijusi su nacionaliniu ES teisès taikymo aspektu. Čia svarbus klausimas, kiek nacionalinè administracinè teisè lemia, kad ji naudojama ES teisei igyvendinti.

Straipsnyje taip pat aptariamos galimybès sukurti pagrindinị ES administracinès teisès vystymo instrumentą - administracinių procedūrų rinkinį ES administracijos santykiams su visuomene.

Mokslinio straipsnio tikslas - nustatyti Europos administracinès teisės galiojimo sritis.

Tyrimo objektas: kadangi, minėta, trejopas požiūris ị Europos administracinę teisę atskleidžia visą Europos administracinès teisès vaizdinį, mūsų straipsnio tyrimo objektas bus ne Europos administracinè teisè stricto sensu ar administracinès teisès europeizacija, bet Europos administracinè teisè kaip ES administracine teise, apimant ir ES

7 Pomahač, R.; Handrlica, J., op. cit., p. 18.

8 Schwarze, J., supra note 3, p. cix.

9 S. Kavalnè rašo, kad administracinès teisès europeizacija - procesas, kai nacionalinė administracinè teisė yra naujai interpretuojama, keičiasi jos turinys, ji yra pildoma ar pakeičiama ES teise. Žr.: Kavalnė, S. Administracinès teisès europeizacija - administraciniams teismams aktualūs klausimai. Administraciniai teismai Lietuvoje. Nüdienos iššūkiai. Vilnius: Lietuvos vyriausiasis administracinis teismas, 2010, p. 212; taip pat žr.: Hendrych, D., et al., supra note 2, p. 714.

10 Bakaveckas, A. Administracinè teisé: teorija ir praktika. Vilnius: Mes, 2012, p. 47, taip pat žr.: RobalinoOrellana, J., et al. Global Administrative Law. Towards a Lex Administrativa. London: CMP Publishing Ltd., 2010.

11 Widdershoven, R. European Administrative Law. Seerden, R., et al. Administrative Law of the European Union, its Member States and the United States: a Comparative Analysis. Oxford: Intersentia Antwerpen, 2007, p. 289-290.

12 Kai kuriuose šaltiniuose vartojama tiek shared government (angl.), tiek shared administration (angl.) sąvokos. Šios sąvokos verčiamos ,padalintas valdymas“ arba „,padalintas administravimas“. 
administracinių procedūrų fenomeną, administracijos bendradarbiavimo teise ir ius commune.

Tyrimo metodai: dokumentų turinio (content) analizès metodas taikomas oficialių (teisès aktų, programų, strategijų, teismo nutarimų) dokumentų rinkimui bei tyrimui. Lyginimo metodu derinama informacija, gauta tiriant skirtingų autorių mokslininkų publikacijas.

\section{Europos administracinès teisès samprata}

Šioje straipsnio dalyje bus remiamasi trimis požiūriais ị Europos administracinę teisę, t. y. Europos administracinè teisé kaip ES administracine teisé, kaip administracinio bendradarbiavimo teise ir kaip ius commune. Tokiu struktūriniu požiūriu vadovaujasi ir kitų šalių administracinès teisès specialistai ${ }^{13}$.

Europos administracinè teisė kaip Europos Sajungos administracinè teisè. Darbo dokumente „ES administracinès teisès būsena bei ateities perspektyvos" Europos Parlamento Teisès reikalų komiteto sudaryta darbo grupe padare išvadą, kad nèra vienos ES administracinès teisès, tačiau yra plejada ịvairių administracinių teisinių režimų, taikomų skirtingoms ES administracijos veiklos sritims. Pasak R. Pomahačo ${ }^{14}$, ES administracinè teisė yra suvokiama kaip savarankiška teisinè sistema, besiskirianti nuo atskirų Europos valstybių teisinių sistemų, t. y. ES administracinè teisé formavosi esant tam tikrai institucinei erdvei: valstybès narès dali savo kompetencijos perdavè integraciniam projektui, buvo įsteigtos institucijos, kurioms buvo suteikti igaliojimai kurti teisès normas bei priimti sprendimus, privalomus valstybėms narėms ir jų viešosioms administracijoms, buvo sukonstruoti valdžių padalijimo tarp organų pagrindai, susidare savita teisinė bendrija, kurioje svarbus vaidmuo teko teismui, galinčiam ne tik spręsti kilusius ginčus, bet ir integruoti teisès aiškinimą bei taikymą. Europos administracinès teisès specialistai ${ }^{15}$, analizuodami ES administracinès teisès fenomeną, paprastai pateikia Europos Bendrijų, o vèliau ES steigimo sutarčių analizę, iš kurios aiškejja, kaip keičiasi Europos institucinis lygmuo, t. y. atskleidžiami konstituciniai administracinès teisès pagrindai, išplaukiantys iš steigimo sutarčių - aiškinama quadripartisme communautaire (Taryba, Komisija, Parlamentas, Teismas) reikšmè, kokiu metodu kuriami ES administracinès teisės reguliavimo aktai, kokie subjektai teikia pasiūlymus antrinės teisės aktams (Komisija), kas juos tvirtina (Taryba, Europos Parlamentas), igyvendina ir kas atlieka ES antrinès teisès aktų igyvendinimo subjektų (Komijos ir valstybių narių institucijos) veiklos kontrolę, atskleidžiama precedentų reikšmė, aiškinama pagrindinių principų (pavyzdžiui, administracijos teisètumo, lygybès, administracinès

13 Pvz., čekų administracinès teisès specialistas R. Pomahač dviejuose savo veikaluose apie Europos administracinę teisę remiasi būtent tokiais požiūriais: Hendrych, D., et al., supra note 2; Pomahač, R.; Handrlica, J., supra note 5.

14 Hendrych, D., et al., op. cit., p. 714.

15 Hendrych, D., et al., op. cit., p. 714-720; Pomahač, R.; Handrlica, J., op. cit., p. 15; Schwarze, J., supra note 3 , p. cxix-clxi. 
pareigos, proporcingumo, teisètų lūkesčių ir teisinio tikrumo apsaugos, tinkamo teisinio proceso, teisminès administracijos kontrolès ${ }^{16}$ ) evoliucionavimo įtaka.

Liuksemburgo universiteto Europos ir transnacionalinès viešosios teisès specialistai $^{17}$ siūlo Europos Sajungos administracinès teisès galiojimo sritis analizuoti trim plačiais aspektais; funkciniu, instituciniu ir procedūriniu. Funkcinis aspektas yra susijęs su administravimo subjektų administracinių užduočių visuma. Čia administracinès funkcijos arba užduotys apima labai platų veiklos, nukreiptos į ES politikos tikslus, spektrą ${ }^{18}$. Pavyzdžiui, šios funkcijos varijuoja nuo individualių sprendimų, parengiamujų aktų iki deleguotos teisėkūros ir pagrindinių teisès aktų keitimo bei jų igyvendinimo, apimdamos jungtinès veiklos planavimą, administracinę teisėkūrą arba privalomą administracinị reglamentavimą (kartu ir teisès normų interpretavimą bei teisès normų ígyvendinimo sąlygų detalizavimą), individualių teisès aktų prièmimą, rekomendacijų, nuomonių, ataskaitų rengimą, jeigu taip yra nustatyta administravimo subjektų teisinị statusą įtvirtinančiuose teisès aktuose, taip pat ịvairų subjektų koordinavimą bei priežiūrą, jeigu jie naudoja ES fondų lèšas, kontroliuoja informacijos valdymą. Institucinio aspekto požiūriu egzistuoja daugybė subjektų, atliekančių administracines funkcijas, igyvendinant ES teisę. Daugeli šių funkcijų atlieka valstybių narių viešojo administravimo subjektai ir čia galioja institucinès autonomijos, arba procedūrinio autonomiškumo, principas $^{19}$, taip pat šias funkcijas igyvendina Komisija, Taryba, agentūros. Taigi institucinio aspekto požiūriu kristalizuojasi plati administracines funkcijas atliekančių institucijų sistema. Procedūrinio aspekto atžvilgiu procedūrinio bendradarbiavimo formų pagrindas yra pasikeitimas informacija bei informacijos generavimas tarp Komisijos, agentūrų bei nacionalinių viešojo administravimo subjektų. Procedūrinio bendradarbiavimo sukuriami ištisi jungtinių planų tinklai, kuriuose atsispindi Komisijos, Europos agentūrų bei nacionalinių viešojo administravimo subjektų veiklos pagrindai. Autoriai šiuos tris aspektus ìvardija kaip ES administracinės teisès poreiki sukurti realų, sistemišką teisinị pagrindą daugiadimensinei sistemos prigimčiai, apimančiai administracinių užduočių, kurias atlieka instituciškai skirtingi, bet procedūriškai susiję subjektai, funkcinę vienovę,

16 The principle of the legality of administration (angl.), the pinciple of equality (angl.), the principle of self-commitment of administration (angl.), the principle of proportionality (angl.), protection of legitimate expectations and legal certainty (angl.), the principle of due process of law (angl.), the control of the administration by the courts (angl.).

17 Herwig, C. H.; Hofmann, C. H., supra note 1, 39-43.

18 Čia mokslininkai pastebi, kad steigimo sutartyse labai trūksta administracinių užduočių ar funkcijų detalizavimo, daugiau detalizuotų atskirų sričių, pavyzdžiui, žemės ūkio, pinigų politikos ir t. t., normų. Žr. Ibid., p. 39.

19 Apie tai plačiau žr.: Ibid., p. 40; Scott, C. Services of General Interest in EC Law: Matching Values to Regulatory Technique in the Public and Privatized Sectors. European Law Journal. 2000, 6 (4): 310-325; Deviatnikovaite, I. Nepriklausomos reguliavimo institucijos valstybinio administravimo instituciju sistemoje. Daktaro disertacija. Socialiniai mokslai (teisè). Vilnius: Mykolo Romerio universitetas, 2012; Valančius, V.; Kavalnè, S., supra note 4, p. 69-73; Case C-51/71-54/71, International Fruit Company e.a. v. Produktschap voor Groenten en fruit [1971] ECR 1107; Case C-39/70, Norddeutsches Vieh - und Fleischkontor GmbH v. Hauptzollamt Hamburg-St. Annen [1971] ECR 49; 
Pasak Europos ombudsmeno ${ }^{20}$, Europos Sajungos administracinė teisė gali būti išskaidyta ị daugybe dalių, pavyzdžiui, administravimo institucijos, administracinès procedūros (apie administracines procedūras žr. antrają straipsnio dalį), kuriomis ịgyvendinamos administracinès užduotys, teisminè, neteisminè priežiūra, pagrindinès teisès ir principai. Autorès nuomone, ES administracinę teisę galima apibrèžti taip: tai Europos viešosios teisès dalis, kurios normomis, išplaukiančiomis iš pirminès ES teisès, nustatoma ES institucijų, atliekančių administracines funkcijas, struktūra, jų kompetencija, tarpusavio santykiai, veiklos principai, santykiai su valstybių narių viešosiomis administracijomis, nustatomi antrinès teisès aktų prièmimo, igyvendinimo mechanizmai, teisminė kontrolè, normomis, išplaukiančiomis iš antrinès ES teisès, nustatomi ES viešosios administracijos (igyvendinimo agentūrų ${ }^{21}$, stebejjimo darinių ${ }^{22}$, bendradarbiavimo agentūrų ${ }^{23}$, vykdomųų agentūrų ${ }^{24}$, agentūrų, atsakingų už įvairių tinklų saugu$\mathrm{mą}^{25}$, nuomones teikiančių agentūrų $\left.{ }^{26}\right)^{27}$ steigimo, funkcijų, veiklos principų, santykių su valstybių narių viešosiomis administracijomis, sprendimų prièmimo bei jų teisètumo kontrolès pagrindai.

20 State of Play and Future Prospects for EU Administrative Law [interaktyvus]. Working Document of Working Group on EU Administrative Law, 2011 [žiūrèta 2013-07-27]. <http://www.europarl.europa.eu/ document/activities/cont/201210/20121025ATT54550/20121025ATT54550EN.pdf>.

21 Pavyzdžiui, Vidaus rinkos harmonizavimo tarnyba, Bendrijos augalų veislių tarnyba, Europos vaistų agentūra, Europos cheminių medžiagų agentūra.

22 Pavyzdžiui, Europos aplinkos agentūra, Europos narkotikų ir narkomanijos stebėsenos centras, Europos maisto saugos tarnyba.

23 Pavyzdžiui, Europos profesinio mokymo plètros centras, Europos gyvenimo ir darbo sąlygu gerinimo fondas, Europos saugos ir sveikatos darbe agentūra.

24 Pavyzdžiui, Europos mokymo fondas, ES ịstaigų vertimo centras.

25 Pavyzdžiui, Europos jūrų saugumo agentūra, Europos aviacijos saugos agentūra, Europos tinklų ir informacijos apsaugos agentūra, Europos geležinkelių agentūra.

26 Pavyzdžiui, Maisto saugos tarnyba, Jūrų saugumo agentūra.

27 Tokią agentūrų klasifikaciją pateikè D. Geradinas ir N. Petit $2004 \mathrm{~m}$. darbiniame dokumente bei mokslinèse ¡žvalgose. Agentūrų klasifikavimo metodų yra ir daugiau, pavyzdžiui, J. Handrlica pateikia materialujị ir formalujį ES agentūrų klasifikavimo būdą. Prie materialiuoju būdu klasifikuojamų agentūrų priskiriamos sprendimus priimančios agentūros (pavyzdžiui, Bendrijos augalų veislių tarnyba, Vidaus rinkos harmonizavimo tarnyba, Europos aviacijos saugos agentūra), kvazireguliacines funkcijas atliekančios agentūros (pavyzdžiui, Europos jūrų saugumo agentūra, Europos maisto saugos tarnyba), koordinavimo funkcijas atliekančios agentūros (pavyzdžiui, Europos aplinkos agentūra, Europos gyvenimo ir darbo sąlygų gerinimo fondas ir t. t.). Prie formaliuoju būdu klasifikuojamų agentūrų priskiriamos reguliacinès agentūros (pavyzdžiui, Europos aplinkos agentūra, Europos aviacijos saugos agentūra), vykdomosios agentūros (pavyzdžiui, Europos mokslinių tyrimų tarybos vykdomoji institucija, Konkurencingumo ir inovacijų vykdomoji įstaiga, Mokslinių tyrimų vykdomoji įstaiga), finansinės priežiūros agentūros (pavyzdžiui, Europos bankininkystės institucija, Vertybinių popierių ir rinkų institucija, Draudimo ir profesinių pensijų institucija). Žr. Geradin, D.; Petit, N. The Development of Agencies at EU and National Levels: Conceptual Analysis and Proposals for Reform. The Jean Monnet Programme [interaktyvus]. Jean Monnet Working Paper, 2004 [žiūrèta 2013-07-10]. <http://centers.law.nyu.edu/jeanmonnet/ papers/04/040101.pdf>; Geradin, D. The Development of European Regulatory Agencies: What the EU Should Learn from American Experience. Columbia Journal of European Law. 2004-2005, 11: 1-52; Deviatnikovaitè, I., supra note 19; Pomahač, R.; Handrlica, J., supra note 5, p. 72-125; Europos Sajungos institucijos ir kitos ịstaigos [interaktyvus]. Europa, 2012 [žiūrèta 2013-08-06]. <http://europa.eu/agencies/ index_en.htm>. 
Europos administracinè teisè kaip administracinio bendradarbiavimo teise arba kaip bendros administracijos erdvés teise. Šios Europos administracinès teisès sampratos susiformavimas yra susijęs su problemomis, kylančiomis dẻl principų ir taisyklių, esančių ne nacionalinės, bet tarptautinių vyriausybinių ar nevyriausybinių organizacijų kilmès, naudojimo, dẻl kolizinių situacijų, atsirandančių susidūrus skirtingoms teisinėms sistemoms, sprendimų būdų, dẻl vyriausybinių ir nevyriausybinių organizacijų bendradarbiavimo vystymosi jų subjektams ịgyvendinant viešaji administravimą ${ }^{28}$. Šiame kontekste vartotinos sąvokos governmentalismus, intergovernmentalismus, infragovernmentalismus. Pirmoji sąvoka taikytina nacionalinès valdžios veiklai, antroji tarpvyriausybinei, trečioji - ES kontekste ES institucijų veiklai. Taigi visiems trims lygmenims atstovaujantys subjektai bendradarbiaudami tarpusavyje yra veikiami globalesnių veiksnių ir susiduria su ịvairiais kitais subjektais, pavyzdžiui, nevyriausybinėmis organizacijomis, viešosiomis korporacijomis. Todèl, kaip teigia R. Pomahačas, šiame kontekste Europos administracinę teisę reikia suvokti kaip valstybių, nevyriausybinių organizacijų, ịvairių korporacijų administracinio bendradarbiavimo teisęę ${ }^{29}$ Čia galime prisiminti įvairiausias daugiašales sutartis žiniasklaidos ir visuomenès informavimo, kultūros paveldo apsaugos, aplinkosaugos ir kitose srityse, pavyzdžiui, Europos laukinès gamtos ir gamtinès aplinkos apsaugos konvencija, Europos architektūros paveldo apsaugos konvencija, Europos konvencija dèl televizijos be sienų, Europos archeologijos paveldo konvencija ir t. t. ${ }^{30}$ R. Pomahačas, aiškindamas Europos administracinę teisę kaip administracinio bendradarbiavimo teise, pateikia Madrido sutarties ${ }^{31}$, Šngeno sutarties, Amsterdamo sutarties, galiausiai Lisabonos sutarties pavyzdžius. Šiuose dokumentuose aptarti teisiniai ir administraciniai klausimai, glaudžiai susiję su nacionalinių viešojo administravimo subjektų bendradarbiavimu laisvès, saugumo ir teisingumo vykdymo srityse.

Europos administracinė teisė kaip ius commune reiškia teisę, kuri yra bendra Europos valstybių viešosioms administracijoms, t. y. čia būdingos bendros sampratos, bendri teisès principai ir bendri pagrindiniai institutai. Ius commune pagrindas yra bendrųų principų pripažinimas daugumoje Europos valstybių viešojoje administracijoje. Todèl daugumos Europos administracinès teisès specialistų veikaluose dažnai aprašomi pagrindiniai principai, pavyzdžiui, lygybės, teisėtumo, diskrecijos, teisinio tikrumo, proporcingumo, viešosios administracijos atsakomybès. R. Pomahačas teigia, kad pagrindinè Europos administracinès teisès ius commune prasme forma yra „ک̌velnioji“ teisé ${ }^{32}$. Čia mokslininkai pateikia dokumentų, kurie turèjo didžiausios reikšmès, for-

28 Tokias priežastis įžvelgia R. Pomahač. Žr. Pomahač, R.; Handrlica, J., supra note 5, p. 19-21; Pomahač, R. Evropské správní právo. Hendrych, D., et al., supra note 2, p. 721.

29 Pomahač, R., Ibid., p. 722.

30 Konvencijų sąrašą žr. Conventions [interaktyvus]. Council of Europe [žiūrèta 2013-08-11]. $<$ http://conventions.coe.int/Default.asp?pg=Treaty/Translations/Translations_lit.htm>.

31 T. y. Europos Konvenciją dèl pasienio bendradarbiavimo tarp teritorinių bendrijų ir valdžios organų, kurios tikslas yra skatinti Europos Tarybos narių savitarpio bendradarbiavimą, o šio tikslo pasiekimui svarbus bendras veikimas administracijos srityje. Žr. Pomahač, R., op. cit., p. 723-727.

32 T. y. Europos Konvenciją dẻl pasienio bendradarbiavimo tarp teritorinių bendrijų ir valdžios organų, kurios tikslas yra skatinti Europos Tarybos narių savitarpio bendradarbiavimą, o šio tikslo pasiekimui svarbus bendras veikimas administracijos srityje. Žr. Pomahač, R., op. cit., p. 730. 
muojantis teisiniams Europos administraciniams standartams Europos Tarybos ribose, pavyzdžius $^{33}$. Taigi Europos administracinè teisè ius commune prasme neapsiriboja ES valstybėmis narèmis. Ji apima ir šalių, ieeinančių ị Europos Tarybą, įsteigtą $1949 \mathrm{~m}$. gegužès 5 d., spektrą. Tačiau Europos administracinè teisè ius commune prasme apima ne tik standartus, pagrịstus ekspertinėmis žiniomis, bet ir žinias, susijusias su atskirų šalių administracinèmis teisinèmis sistemomis. Todèl čia didelę reikšmę iggyja lyginamoji administraciné teisé, t. y. ịvairių administracinių teisinių sistemų analizė lyginamuoju aspektu.

Analizuojant Europos administracinès teisès reiškinị, ko gero, reikètų atsižvelgti ir ị patị Europos administracinès teisès turinį, kurị autoriai apima, aprašydami šią viešosios teisės dali. Pavyzdžiui, pagal J. Schwarze'ą, Europos administracinès teisės galiojimo sritys apima Europos administracijos sampratą, sektorius, kuriuose iggyvendinama ES teisè (tiesioginis, netiesioginis igyvendinimas), Europos administracinès teisès šaltinius (rašytiniai (pirminiai, antriniai), papročių teisè, teismų praktika bei pagrindiniai principai), esminius administracinių teisinių sistemų bruožus valstybėse narèse, teisètumo, diskrecijos, lygybés, diskriminacijos draudimo, proporcingumo, teisinio tikrumo, administracinių procedūrų teisinės valstybės kontekste principų reikšmės analizę ịvairiose valstybėse narèse bei pačioje ES, ES tarnybą, bendrų rinkų (pvz., energetikos, žemès ūkio) bei konkurencijos reguliavimą. Kiti autoriai, pavyzdžiui, R. Pomahačas ir J. Handrlica, Europos administracinei teisei priskiria Europos administravimo aplinkos analizę (viešojo administravimo formas, Europos administracinès teisès sampratų ịvairovę, globalios administravimo aplinkos konstitucionalizavimą), Europos administracinès teisès šaltinius, principus, taip pat Europos agentūrų fenomeną, jų funkcijas, steigimo pagrindus, įvairovę, taip pat agentūrų administracinius aktus bei jų administracinę kontrolę.

Europos administracinès teisès sampratoje nemažas vaidmuo tenka principams, kuriais ES administracija įgyvendinant ES teisę turi vadovautis santykiuose su visuomene, maža to, sakoma, kad ,administracinių procedūrų/proceso rinkinio sudarymas ir prièmimas yra esminis instrumentas vystant administracinę teisę ${ }^{\text {(334 }}$, todèl kitoje straipsnio dalyje aptarsime ES administracinių procedūrų rinkinio fenomeną.

33 Žr. Schwarze, J., supra note 3, p. 95; Hendrych, D., et al., supra note 2, p. 730. Pavyzdžiui, po to, kai Europos Taryba 1975 m. išleido knygą "The Protection of the Individual in Relation to Acts of Administrative Authorities: An Analytical Survey of the Rights of the Individual in the Administrative Procedure and His Remedies Against Administrative Acts" Europos Tarybos Ministrų Komitetas prièmé rezoliuciją Nr. (77) 31, kuria nustate tolesnes asmenų teisių apsaugos nuo viešosios administracijos neteisètų veiksmų gaires. Šios rezoliucijos pagrindu buvo priimta nemažai rekomendacijų, kurios sudaro dabartinių administracinès teisès europinių nuostatų pagrindą. Pavyzdžiui, Europos Tarybos Ministrų Komiteto rekomendacija Nr. (81) 2 dèl atviros administracijos, rekomendacija Nr. (84) 15 dèl viešosios administracijos atsakomybės, rekomendacija Nr. (2001) 9 dèl alternatyvių ginčų tarp viešojo administravimo institucijų ir privačių asmenų sprendimo priemonių, rekomendacija Nr. (2003) 16 dèl administracinių ir teisminių sprendimų administracinès teisès srityje įgyvendinimo, rekomendacija Nr. (2004) 20 dẻl administracinių aktų teisminès kontrolès ir t. t.

34 Meuwese, A.; Schuurmans, Y.; Voermans, W. Towards a European Administrative Procedure Act. Review of European Administrative Law. 2009, 2 (2): 5. 


\section{ES administracinių procedūrų rinkinio rengimo prielaidos}

Rašant apie ES administracines procedūras, pirmiausia reikètų atkreipti dèmesi i termino ,administracinis procesas“ vartojimo kontekstą, kadangi administracinių procedūrų rinkinio rengimo dokumentuose skirtingomis kalbomis vartojami tiek proceso, tiek procedūrų terminai. Mokslinejje literatūroje anglų kalba bei anglų kalba pateiktuose dokumentuose yra vartojamas administrative procedure (angl.) terminas. JAV egzistuoja teisès aktas, taikomas agentūroms, administracinès teisès teisèjams bei teismams ${ }^{35}$. Čia turimas mintyje Administrative Porcedure Act (angl.), kurị autorè verčia ne kaip „administracinių procedūrų kodeksas“, bet kaip ,administracinio proceso kodeksas“, nes šis teisès aktas neapsiriboja vien tik viešosios administracijos administracinėmis procedūromis. Europos Parlamento išleistos rezoliucijos su rekomendacijomis Komisijai dèl ES administracinių procedūrų kodekso angliškame vertime taip pat vartojamas terminas administrative procedure. Vokiškame šio dokumento vertime vartojamas terminas Verwaltungsverfahrensrecht (vok.). Šis terminas reiškia administraciniu procedūrų teisę $e^{36}$. Štai ir vokiečių mokslininkas J. Schwarze'as ${ }^{37}$ savo straipsnyje skiria dvi sąvokas - administracinè procedūra ir teisminè priežiūra. Tačiau šis autorius teigia, kad pagrindine ES Teisingumo Teismo ir Pirmosios instancijos teismo misija yra užtikrinti sąžiningą ir nešališką administracinị procesą. Taigi čia sutapatinamos administracinės procedūros ir administracinio proceso sąvokos. Kita vertus, iš čia išplaukia, kad minètų ES teismų veikla taip pat yra dalis ES administracinio proceso (juk ES teismai prižiūri ne tik ES institucijų, bet ir ES įstaigų, organų, taip pat agentūrų priimtų teisès aktų teisètumą $\left.{ }^{38}\right)^{39}$. Lietuviškame, čekiškame, bulgariškame, portugališkame, slovėniškame minèto dokumento vertime vartojamas administracinio proceso terminas. Pabrèžiame, kad priimamas ES administracinių procedūrų kodeksas nèra skirtas ES teismams. Jis būtų taikomas ES institucijoms, įstaigoms, biurams ir agentūroms, t. y. ES administracijai jos santykiuose su visuomene. Kitaip tariant, minėtas teisès aktas yra administracinių

35 Minèto kodekso nuo 701 iki 706 paragrafo.

36 Vokiečiai turi du teisės aktus: Administracinių procedūrų kodeksą (Verwaltungsverfahrensgesetz), taikomą pagal šio teisès akto pirmą skyrių viešojo administravimo subjektams, jiems ịgyvendinant administracinę veiklą, bei Administracinių teismų procedūrų kodeksą (Verwaltungsgerichtsordnung), taikomą administraciniams teismams.

37 Schwarze, J. Judicial Review of European Administrative Procedure. Law and Contemporary Problems. 2004: 85-105.

$38 Z \breve{Z r}$.: Europos Parlamento ir Tarybos 2009 m. balandžio 23 d. reglamentas 401/2009 dèl Europos aplinkos agentūros bei Europos aplinkos informacijos ir stebėjimo tinklo. [2009] OL, L 126; Europos Parlamento ir Tarybos 2009 m. liepos 13 d. reglamentas (EB) Nr. 713/2009, insteigiantis Energetikos reguliavimo institucijų bendradarbiavimo agentūrą. [2009] OL, L 211; Tarybos 1975 m. gegužès 26 d. reglamentas 1365/75 dèl Europos gyvenimo ir darbo sąlygų gerinimo fondo įsteigimo. [1975] OL, L 139; Europos Parlamento ir Tarybos 2006 m. gruodžio 20 d. reglamentas 1922/2006, įsteigiantis Europos lyčių lygybès institutą. [2006] OL, L 403; Europos Parlamento ir Tarybos 2006 m. gruodžio 12 d. reglamentas 1920/2006 dèl Europos narkotikų ir narkomanijos stebėsenos centro (nauja redakcija). [2006] OL, L 376 ir t. t.

39 Minètas autorius teigia, kad administracinių procedūrų teisè (manytina, čia turèta galvoje administracinio proceso teisè) yra „paremta“ dviem ramsčiais, t. y. rašytine teise (tiek pirmine, tiek antrine ES teise) ir ES teismų praktika. Ibid.,p. 87. 
procedūrų, kuriomis vadovaujasi ES administracija savo veikloje, rinkinys. Čia galima iškelti klausimą - kodèl šis teisès aktas neapima ES teismų kompetencijos? Atsakymas i ̌ ši klausimą būtų toks - Sutartis dèl ES veikimo apibrèžia, ,išbaigtą teisinių gynimo priemonių bei procedūrų sistemą, sukurtą Teisingumo Teismui ir Pirmosios instancijos teismui kontroliuoti ES institucijų veiklos teisètumą “40, taigi reikètų keisti Sutartí dèl ES veikimo, naikinti protokolą Nr. 3 ir visas jų normas perkelti į ES administracinio proceso kodeksą.

Nepaisant Lietuvoje susiklosčiusios administracinio proceso sampratos ${ }^{41}$, taip pat to, kad ES teisèje nèra oficialaus administracinių procedūrų apibrèžimo, autorè priimamo teisès akto kontekste siūlo vartoti administracinių procedūrų terminą, nes šis teisès aktas apims ne visas administracinio proceso galiojimo sritis.

Rengiant arba mažų mažiausiai apmąstant Europos administracines procedūras reglamentuojantị teisès aktą, atspirties taškais, pripažinta, yra Sutarties dẻl ES veikimo 298 straipsnis, kuriame nustatomi pagrindiniai ES institucijų, įstaigų ir organų, t. y. administracijos, veiklos principai - atvirumas, veiksmingumas, nepriklausomumas - bei įtvirtinama, kad Europos Parlamentas ir Taryba tuo tikslu turi patvirtinti nuostatas, taip pat ES pagrindinių teisių chartijos 41 ir 42 straipsniai, kuriuose yra įtvirtinama žmogaus teisè i gerą administravimą ir teisè susipažinti su dokumentais, taip pat pagrindiniai principai (pavyzdžiui, procesinès teisès, teisès akto teisètumo kontrolès, lygybès, diskrecijos, proporcingumo, teisinio tikrumo ir kiti principai), kuriuos suformulavo ir išvystė savo praktikoje ES Teisingumo Teismas, Europos ombudsmeno parengtas Europos tinkamo administravimo elgesio kodeksas, taip pat Gero administravimo elgesio kodeksas Europos Komisijos personalui santykiuose su visuomene (pastarieji du teisès aktai dar vadinami ,švelniaja teise“ $)^{42}$. Tačiau prieš apžvelgiant Europos administracinių procedūrų rinkinio kūrimo prielaidas, pirmiausia atkursime chronologinę eigą, vedančią link ES administracinių procedūrų kodekso.

Europos Parlamentas dar 2001 metų rudenį, kai tvirtino Europos tinkamo administravimo elgesio kodeksą, kartu kreipèsi ir ị Europos Komisiją dèl galimybės pateikti konkrečius pasiūlymus parengti administracinių procedūrų nuostatoms. Vèliau administracinių procedūrų tematika buvo plètojama praktiniu-moksliniu lygmeniu. Pavyzdžiui, Europos Parlamento Teisės reikalų komitetas 2010 m. liepą sudarė ES administracinès

40 Schwarze, J., supra note 38, p. 85. Žr.: Sutarties dèl ES veikimo 5 skirsnį (straipsniai nuo 251 iki 281), 228 str., 245 str., 247 str., 348 str., taip pat Protokolo Nr. 3 Dėl ES Teisingumo Teismo Statuto bei ES sutarties suvestinès redakcijos 19 str.; ịvairių ES agentūrų reglamentus.

41 Administracinis procesas -,,tai kompetentingų valstybės institucijų < ..> veikla, skirta spręsti viešojo administravimo srityje kylančius klausimus...", procesas gali būti suprantamas kaip tam tikros procedūros, t. y. tam tikra „proceso vidinè dinamika“, žr.: Šedbaras, S. Administracinio proceso teisinio reglamentavimo problemos Lietuvos Respublikoje. Vilnius: Justitia, 2006, p. 61-69.

42 Žr.: Sutartis dèl Europos Sajungos veikimo (suvestinè redakcija). [2010] OL, C 83; Europos Sajungos pagrindinių teisių chartija. [2010] OL, C 83/02; Europos tinkamo administravimo elgesio kodeksas [interaktyvus]. Europos Parlamentas [žiūrèta 2013-07-27]. <http://www.lrski.lt/document_db/tfiles/106. doc>; Code of Good Administrative Behaviour for Staff of the European Commission in their Relations with the Public [interaktyvus]. Europos Komisija [žiūrèta 2013-07-28]. <http://ec.europa.eu/transparency/ civil_society/code/_docs/code en.pdf>; Case C-1/73, Westzucker GmbH and Gebrüder Dietz v. Hoofdproduktschap voor Akkerbouwprodukten. [1973] ECR 723. 
teisès darbo grupę ${ }^{43}$, kuri $2011 \mathrm{~m}$. spali išleido darbo dokumentą „ES administracinès teisès būsena bei ateities perspektyvos“"44. 2012 m. kovą Europos Parlamente vyko konferencija „Towards an EU Administrative Procedure Law?“"45 (ang1.), kurią surengè Europos ombudsmenas kartu su Europos Sajungos administracinès teisès tyrimų tinklu $\left(\right.$ ReNEUAL) ${ }^{46}$, taip pat 2012 m. kovą Teisès reikalų komitetas kreipèsi ị Poveikio vertinimo ir Europos pridėtinès vertės direktoratą (Europos Parlamento Generalinio sekretoriato ES vidaus politikos generalinio direktorato struktūrinị dalinị) paremti iniciatyvą ir pateikti rekomendacijas Komisijai rengiant ES administracinių procedūrų kodeksą. Poveikio vertinimo ir Europos pridėtinès vertès direktoratas $2012 \mathrm{~m}$. spalị paviešino leidinị „ES administracinių procedūrų kodeksas“"47. Pagaliau 2013 m. sausị Europos Parlamentas išleido rezoliuciją su rekomendacija Komisijai dẻl ES administracinių procedūrų kodekso $^{48}$. Toliau apžvelgsime visus nurodytus šaltinius pagal du kriterijus - kodifikavimo poreiki ir ES administracinių procedūrų kodekso turinį.

Tiek darbo dokumente „ES administracinès teisès būsena bei ateities perspektyvos“, tiek konferencijoje „Towards and EU Administrative Procedure Law?“ Europos Parlamento Teisės reikalų komiteto sudaryta darbo grupé bei Europos ombudsmenas su ReNEUAL, taip pat Poveikio vertinimo ir Europos pridėtinès vertès direktoratas (leidinyje „ES administracinių procedūrų kodeksas ${ }^{6}$ ) pripažįsta, kad Europos administracinių procedūrų taisyklès vystosi fragmentiškai, kad jų galima atrasti teisės aktuose, reguliuojančiuose tam tikras sritis, o daugiausia bendro pobūdžio administracinių procedūrų taisyklių yra steigimo sutartyse, ES pagrindinių teisių chartijoje, Europos Sajungos Teisingumo Teismo praktikoje ir reglamentuose. Pavyzdžiui, reglamente dèl galimybès visuomenei susipažinti su Europos Parlamento, Tarybos ir Komisijos dokumentais yra išdèstytos tam tikros procedūrinès garantijos (7,8 straipsniai), reglamente dèl asmenų apsaugos Bendrijos institucijoms ir ịstaigoms tvarkant asmens duomenis ir laisvo tokių duomenų judejjimo taip pat yra įtrauktos administracines procedūras reglamentuojančios normos (47, 49 straipsniai), Sutarties dèl ES veikimo 258 straipsnyje reglamentuojami Komisijos santykiai su valstybe nare ir ES Teisingumo Teismu, jei valstybè narè nei-

43 Šiai darbo grupei buvo iškelta keletas užduočių: pirma, indetifikuoti dabartinę ES administracinės teisès padètị, antra, pasiūlyti teisinị reguliavimą, susijusị su Sutarties dèl ES veikimo 298 straipsniu.

44 State of Play and Future Prospects for EU Administrative Law [interaktyvus]. Working Document of Working Group on EU Administrative Law, 2011 [žiūrèta 2013-07-27]. <http://www.europarl.europa.eu/ document/activities/cont/201210/20121025ATT54550/20121025ATT54550EN.pdf>.

45 „Towards an EU Administrative Procedure Law?“ Towards an EU Administrative Procedure Law? [interaktyvus]. Brussels, March $15^{\text {th }}-16^{\text {th }}-$ (draft) [žiūrèta 2013-07-23]. $<$ http://www.reneual.eu/events/ED conference/ReNEUAL_conference_March_2012/Conference\%20Report\%20Brussels\%20March\%20 15 Th\%20\%2016Th.pdf>.

46 Angliškas trumpinys, reiškiantis Research Network on EU Administrative Law. Žr. ReNeual [interaktyvus]. [žiūrèta 2013-07-26]. <http://www.reneual.eu/>.

47 Law on Administrative Procedure of the European Union [interaktyvus]. European Added Value Assessment, 2012 [žiūrèta 2013-07-26]. < http:/www.europarl.europa.eu/meetdocs/2009_2014/documents/ juri/dv/eav_lawofadminprocedure_EAV_Lawof Adminprocedure_EN.pdf $>$.

48 Europos Parlamento 2013 m. sausio 15 d. rezoliucija Nr. 2012/2024(INI) dèl Europos Sajungos administracinio proceso kodekso [interaktyvus]. Strasbūras, 2013 [žiūrèta 2013-07-26]. <http://www.europarl. europa.eu/sides/getDoc.do?pubRef=-//EP//TEXT+TA+P7-TA-2013-0004+0+DOC+XML+V0//LT>. 
vykdè kokios nors pareigos, minètos sutarties 336 straipsnyje užfiksuoti tarnybiniai santykiai. Maža to, ES agentūrų teisinị statusą reglamentuojančiuose teisės aktuose esama skirtingu lygmeniu įtvirtintų administracinių procedūrų ${ }^{49}$. Minètame darbo dokumente paaiškinama, kad administracinių procedūrų ịvairovè yra suponuota administracinès kultūros daugialypiškumo, būdingo skirtingoms ES institucijoms ir netgi skirtingiems joms pavaldiems dariniams (direktoratams). Konferencijoje „Towards and EU Administrative Procedure Law?" dalyvavusiu praktikų ir mokslininkų nuomone, toks fragmentiškumas ir nevienalytiškumas apsunkina galimybes sukurti vieną ES administracines procedūras reglamentuojantị dokumentą. $\mathrm{O}$ minètas direktoratas pabrěžia, kad fragmentiškumas ${ }^{50}$ ir spragos daro administracines procedūras labai skirtingas, maža to, kai kuriuose sektoriuose aiškiai trūksta taisyklių, garantuojančių piliečių, rinkų dalyvių, kitų juridinių asmenų teises.

Anksčiau nurodytame darbo dokumente mokslininkai nurodo įvairias ES administracinių procedūrų kodifikavimo formas. Pirma, kodifikavimas pagal sektorius. Antra, dalinis kodifikavimas, reiškiantis kodifikavimą specifinio bendrosios administracinès teisès aspekto atžvilgiu. Trečia, horizontalus kodifikavimas (pavyzdžiui, Tinkamo gero administravimo elgesio kodekso ir ES pagrindinių teisių chartijos nuo 41 iki 47 straipsnių kodifikavimas). Ketvirta, inovatyvus kodifikavimas, reiškiantis, kad rengiamas visiškai naujas teisès aktas, penkta, grynasis kodifikavimas, reiškiantis sudaromą teisiniu požiūriu privalomą konsoliduotą egzistuojančių teisès aktų rinkinį.

Konferencijoje „Towards and EU Administrative Procedure Law?"51 ES administracinès teisès specialistai ịvardijo ES administracinių procedūrų kodekso poreikị grindžiančias priežastis. Pirma, integruotos administracijos vystymasis palieka daugybę neišspręstų procedūrų klausimų. Nesugebèjimas nustatyti aiškias, prognozuojamas taisykles sukelia atskaitomybės trūkumą bei palaipsniui griauna teisès viršenybės principą (angl. rule of law) Europos Sajungoje. Antra, kodifikavimas būtų geriausias būdas institucijoms, biurams, agentūroms ịgyvendinti Sutarties dèl ES veikimo 298 straipsnį bei

49 Europos Parlamento ir Tarybos 2001 m. gegužès 30 d. reglamentas (EB) Nr. 1049/2001 dèl galimybės visuomenei susipažinti su Europos Parlamento, Tarybos ir Komisijos dokumentais. [2001] OL, L 145; Europos Parlamento ir Tarybos 2000 m. gruodžio 18 d. reglamentas 45/2001 dèl asmenų apsaugos Bendrijos institucijoms ir įstaigoms tvarkant asmens duomenis ir laisvo tokių duomenų judejimo. [2000] OL, L 8; Sutartis dèl Europos Sajungos veikimo (suvestinè redakcija). [2010] OL, C 83; State of Play and Future Prospects for EU Administrative Law [interaktyvus]. Working Document of Working Group on EU Administrative Law, 2011 [žiūrèta 2013-07-27]. <http://www.europarl.europa.eu/document/ activities/cont/201210/20121025ATT54550/20121025ATT54550EN.pdf>.

50 Pasak direktorato, administracinių procedūrų užuomazgų galima rasti vidiniuose ES administracijos dokumentuose ir „švelniojoje teisèje“, t. y. elgesio kodeksuose, neprivalomuose dokumentuose. Direktorato nuomone, būtina sukurti privalomą bendrą dokumentą, garantuojantị žmonėms jų teises santykiuose su ES administracija. Žr. Law on Administrative Procedure of the European Union [interaktyvus]. European Added Value Assessment, 2012 [žiūrèta 2013-07-26]. <http://www.europarl.europa.eu/ meetdocs/2009_2014/documents/juri/dv/eav_lawofadminprocedure_/EAV_LawofAdminprocedure_ EN.pdf $>$.

51 „Towards an EU Administrative Procedure Law?" Towards an EU Administrative Procedure Law? [interaktyvus]. Brussels, March $15^{\text {th }}-16^{\text {th }}-$ (draft) [žiūrèta 2013-07-23]. $<$ http://www.reneual.eu/events/ED conference/ReNEUAL_conference_March_2012/Conference $\% 20$ Report $\% 20$ Brussels $\% 20 \mathrm{March} \% 20$ $15 \mathrm{Th} \% 20 \% 2016 \mathrm{Th} . \mathrm{pdf}>$. 
vystant pagrindinę teisę orientuojantis ị gerą administravimą, įtvirtintą ES pagrindinių teisių chartijos 41 straipsnyje. Trečia, ES administracinio proceso kodifikavimas padidintų teisinį skaidrumą ir tikrumą. Ketvirta, kodeksas apibendrintų, sistemizuotų procesines nuostatas, kurios dabar yra išplitusios daugybės sektorių teisès aktuose, ịvairių Europos teismų sprendimuose. Penkta, kodifikavimas sistemiškai standartizuotų pagrindines ES administracijos proceso taisykles bei principus, sukurtų vienalyti pagrindą visai ES administracijai. Šešta, kodifikavimas suteiktų ES teisiniam reguliavimui stabilumo ir būtų tam tikras matas, toliau vystantis sektoriams ir administracijai. Septinta, kodeksas palengvintų institucijų dalią priimant sprendimus, nes joms nebereikètų derètis dèl procedūrinių aspektų. Pagaliau - toks modelis gali būti eksportuojamas i kitus pasaulio regionus. Mokslininkai siūlè ịvairius būsimojo ES administracinių procedūrų rinkinio modelius. Pavyzdžiui, vieni teigè, kad, rengiant administracinių procedūrų kodeksą, reikètų atsižvelgti ị keletą teisinių technikų, kurias yra išvysčiusi JAV, t. y. teisès normų sąvado rengimo techniką. Jų nuomone, toks požiūris padètų nuosekliau, aiškiau vertinti jau egzistuojančias materialiąsias ES administracines normas bei padètų užpildyti esamas spragas. Kiti teigė, kad būtina suderinti ES administracinių procedūrų reguliavimą su valstybių narių administracinių procedūrų ar administracinių procesų kodeksais. Konferencijoje mokslininkai bei praktikai pristate keturias pagrindines sritis, kurios sudarytų ES administracinio proceso kodekso pagrindą. Tai - bendrojo pobūdžio teisès aktų prièmimo procesas, individualaus pobūdžio teisès aktų prièmimo procesas, ES informacijos tinklas, viešosios ES sutartys.

Poveikio vertinimo ir Europos pridètinès vertès direktoratas leidinyje „ES administracinių procedūrų kodeksas“" pripažino neabejotiną poreikį sukurti gero administravimo bendrus administracinius principus ir procedūrines taisykles. Direktoratas, remdamasis skundų ir bylų pavyzdžiais, siūlo aiškesnę gero administravimo principų sistemą - nešališkumo, sąžiningumo, teisėtumo, nediskriminavimo ir vienodo elgesio, proporcingumo, protingų terminų, teisès kiekvienam būti išklausytam, pareigos pagrịsti sprendimus, bendravimo su ES institucijomis bet kuria ES kalba principus. Taip pat direktoratas siūlo ị būsimajị kodeksą ịtraukti pagrindines procedūrines taisykles ir standartus, kurių laikytųsi ES administracija, nagrinėdama individualius atvejus. Labiausiai kritikuojama tai, kad dažnai ES piliečiai nè nežino, kada ES administracija priims vieną ar kitą sprendimą jų atžvilgiu. Kyla problemų ir skundų registravimo srityje, asmenys ne visada informuojami apie skundo nagrinejimo etapus. Taip pat akcentuojamos biurokratinès finansavimo programų administravimo problemos piliečiams tiesiogiai kontaktuojant su Komisija ar agentūromis, taip pat pastebima, kad institucijos dažnai pateikia netikslią informaciją. Todèl, direktorato nuomone, administracinių procedūrų rinkinyje turi būti nuostatos dèl administracinès procedūros pradẻjimo, dèl prašymų gavimo patvirtinimo, dèl pareigos pagristi sprendimus ir juos taisyti. Tokios nuostatos, pasak direktorato, būtų naudingos, jei jos būtų visai ES administracijai vienodos. Direktoratas taip pat apibrèžia kodekso statusą - jis turètų apsiriboti tiesioginiu administravimu ir turi būti taikomas kaip lex generalis visoms ES veiklos sritims. Tuo tarpu lex specialis gali būti naudojamas tuomet, kai reikia specifinèje srityje labiau detalizuotų procedūrų. Toks reguliavimas, direktorato nuomone, užtikrintų tinkamesnị Teisingumo Teismo vaidmenị 
administracinių sprendimų atžvilgiu, juk jis turi prižiūrèti, ar korektiškai buvo laikomasi procedūrų, aukštesnès galios teisès aktų. Tuo tarpu šiuo metu administracinès procedūros yra ịtvirtintos daugiausia „švelniojoje teisèje“, o tai leidžia ES teismams spręsti patiems, kokiai normai atitinkamoje situacijoje suteikti didesnę reikšmę. Manoma, kad toks kodeksas padidins ES administracijos skaidrumą ir jos prieinamumą piliečiams. Be to, direktoratas pabrěžia, kad toks dokumentas palengvintų ES teismų darbą, jiems nebereikètų gaišti laiką ieškant atitinkamų vidinių teisès aktų. Direktorato narių nuomone, toks kodeksas sumažintų ir antrinių teisės aktų teisės normų skaičių - juk reikètų ištrinti tam tikras bendrąsias administracinès teisès nuostatas iš atitinkamus sektorius reguliuojančių antrinių teisès aktų. Direktoratas remiasi ir valstybių narių patirtimi, kurios, vis daugejjant administracinės teisės galiojimo sričių, priima nacionalinio lygmens administracinių procedūrų ịstatymus, pavyzdžiui, Vokietija, Suomija, Nyderlandai (iš viso 20 valstybių narių iš 28 turi panašaus pobūdžio teisès aktus).

2013 m. sausi Europos Parlamento išleistoje rezoliucijoje su rekomendacijomis Komisijai dèl ES administracinių procedūrų kodekso (lietuviškame dokumento vertime vartojamas ES administracinio proceso teisès terminas) akcentuojamos priežastys parengti administracinio proceso kodeksą. Kai kurias jų nurodysime. Pirma priežastis ta, kad piliečiams vis dažniau tenka susidurti su ES administracija, o procesinès pirmujų teisès nèra visiškai garantuojamos. Antra, dokumente pabrěžiama, kad gero administravimo taisyklès ir principai išdėstyti ịvairiuose šaltiniuose: pirminèje teisèje, ES Teisingumo Teismo praktikoje, antriniuose teisès aktuose, privalomos teisinės galios neturinčiuose teisės aktuose ir vienašaliuose ES institucijų ịsipareigojimuose, taip pat ịvairių institucijų elgesio vidaus kodeksuose, kurie yra skirtingi ir teisiniu požiūriu neprivalomi. Tai reiškia, kad administracinio proceso taisyklės yra išsklaidytos ir nevienalytės. Trečia, pripažįstama, kad ES nėra „nuoseklaus ir išsamaus kodifikuotų administracinės teisès taisyklių sąvado", o tai daro ES administracinę teisę piliečiams sunkiai suprantamą. Ketvirta, ES procedūrų kodeksas pagerintų ES administracijos veiklos teisètumą, o tai padidintų ES piliečių pasitikejjimą. Minimos rezoliucijos rekomendacijose ryškejja ES administracinių procedūrų kodekso struktūra. Pirmoje kodekso dalyje turi atsispindèti tikslas ir taikymo sritis, akcentuojant gerą administravimą, kurio turi laikytis ES administracija (t. y. ES institucijos, įstaigos, biurai, agentūros), apsiribojant tiesioginiu administravimu. Nurodyta, kad kodekse turi būti ịtvirtinti pagrindiniai gero administravimo principai ir reglamentuojamos procedūros, kuriomis vadovautųsi ES administracija santykiuose su fiziniais ar juridiniais asmenimis. Antroje kodekso dalyje turi būti nurodyta, kad kai nèra lex spcialis, taikoma de minimis taisyklè. Trečioje kodekso dalyje turi būti kodifikuoti teisètumo, nediskriminavimo ir vienodo požiūrio, proporcingumo, nešališkumo, nuoseklumo ir teisètų lūkesčių, pagarbos privatumui, sąžiningumo, skaidrumo, veiksmingumo ir aptarnavimo principai. Ketvirtoje kodekso dalyje nurodyti dešimt punktų, kuriais reglamentuojamos administracinių sprendimų prièmimo taisyklès (administracinès procedūros pradèjimas, prašymų gavimo patvirtinimas, terminai, administracinių sprendimų formos, kalba, sprendimų pagrindimas, pranešimas apie administracinius sprendimus, teisiniu gynimo priemonių nurodymas). Penktoje dalyje turi būti numatytos galimybès ES administracijai taisyti klaidas. Paskutine rekomenda- 
cija Europos Parlamentas siūlo Komisijai parengti ES administracinių procedūrų kodeksą lengvai suprantama kalba, aiškiai ir glaustai.

Akivaizdu, kad tiek mokslininkai, tiek praktikai labai panašiai pagrindžia ES administracinių procedūrų kodekso poreikị: administracinių procedūrų reglamentavimo nevienalytiškumas, fragmentiškumas, dèl to kylančios problemos, susijusios su ES administracijos prieinamumu. Visiškai vieningai sutariama ir dèl administracinių procedūrų rinkinio statuso - privalomas visiems ES administracijos subjektams. Iš esmès sutariama ir dèl rinkinio turinio - jis neturi apimti kitų administracinio proceso galiojimo ribų, t. y. teisminio proceso. Taigi šis dokumentas yra skirtas ịtvirtinti administracines procedūras, kuriomis turi vadovautis ES administracija santykiuose su visuomene.

\section{Išvados}

1. Sąvoka „Europos administracinė teise்“ yra platesnè už sąvoką „ES administracinè teiséc. Europos administracinè teisè gali būti suvokiama ne tik kaip teisès dalis, nustatanti ES administracijos teisinị statusą, jos veiklos principus, formas ir metodus, teisètumo kontrolès institutus, bet ir kaip administracinio bendradarbiavimo tarp valstybių, nevyriausybinių organizacijų, ịvairių korporacijų teisé, pagrịsta ịvairiausiomis daugiašalėmis sutartimis ar konvencijomis, peržengiančiomis ES ribas. Maža to, Europos administracinę teisę galima suvokti kaip teisę su bendromis sąvokomis, Europos valstybių viešosioms administracijoms bendrais teisès principais, taip pat kaip mokslą, lyginantị ịvairių Europos valstybių administracines teisines sistemas.

2. Vystant ES administracinę teisę, manytina, svarbu nustatyti vienodus ES administracijos veiklos santykiuose su visuomene pagrindus. Egzistuoja keletas svarbių priežasčių, kodèl būtina parengti ES administracinių procedūrų kodeksą. Pirma, ES reikalingas bendras privalomojo pobūdžio teisès aktas, kuriame būtų nustatytos aiškios ES administracijos veiklos taisyklès santykiuose su juridiniais ir fiziniais asmenimis ir kuriuo būtų padidintas ES administracijos skaidrumas bei jos prieinamumas piliečiams. Antra, ES procedūrų kodekso rengimo prielaidos yra ir teisinès. Čia svarbus Sutarties dèl ES veikimo 298 straipsnis, ES pagrindinių teisių chartijos 41 ir 42 straipsniai bei ,ک̌velnioji teisé“", t. y. administravimo elgesio kodeksai.

\section{Literatūra}

Bakaveckas, A. Administracine teisé: teorija ir praktika. Vilnius: Mes, 2012.

Case C-51/71-54/71, International Fruit Company e.a. v. Produktschap voor Groenten en fruit [1971] ECR 1107.

Case C-39/70, Norddeutsches Vieh - und Fleischkontor GmbH v. Hauptzollamt Hamburg-St. Annen [1971] ECR 49.
Case C-1/73, Westzucker GmbH and Gebrüder Dietz v. Hoofdproduktschap voor Akkerbouwprodukten [1973] ECR 723.

Conventions [interaktyvus]. Council of Europe [žiūrèta 2013-08-11]. <http://conventions. coe.int/Default.asp?pg=Treaty/Translations/ Translations_lit.htm>. 
Deviatnikovaitè, I. Nepriklausomos reguliavimo institucijos valstybinio administravimo instituciju sistemoje. Daktaro disertacija. Socialiniai mokslai (teisè). Vilnius: Mykolo Romerio universitetas, 2012.

Europos Parlamento 2013 m. sausio 15 d. rezoliucija Nr. 2012/2024(INI) dèl Europos Sajungos administracinių procedūrų kodekso [interaktyvus]. Strasbūras, 2013 [žiūrèta 2013-07-26]. <http:// www.europarl.europa.eu/sides/getDoc. do? pubRef=-//EP//TEXT+TA+P7-TA2013-0004+0+DOC+XML+V0//LT>.

Europos Parlamento ir Tarybos $2001 \mathrm{~m}$. gegužès 30 d. reglamentas (EB) Nr. 1049/2001 dèl galimybès visuomenei susipažinti su Europos Parlamento, Tarybos ir Komisijos dokumentais. [2001] OL, L 145.

Europos Sajungos institucijos ir kitos įstaigos [interaktyvus]. Europa, 2012 [žiūrèta 201308-06]. <http://europa.eu/agencies/index_ en.htm>.

Europos Sajungos pagrindinių teisių chartija. [2010] OL, C 83/02.

Europos tinkamo administravimo elgesio kodeksas [interaktyvus]. Europos Parlamentas, 2001 [žiūrèta 2013-07-27]. <http://www. lrski.lt/document_db/tfiles/106.doc $>$.

Geradin, D. The Development of European Regulatory Agencies: What the EU Should Learn from American Experience. Columbia Journal of European Law. 2004-2005, 11: $1-52$.

Geradin, D.; Petit, N. The Development of Agencies at EU and National Levels: Conceptual Analysis and Proposals for Reform. The Jean Monnet Programme [interaktyvus]. Jean Monnet Working Paper, 2004 [žiūrèta 2013-07-10]. <http://centers. law.nyu.edu/jeanmonnet/papers/04/040101. pdf $>$.

Hendrych, D., et al. Správní právo. Obecná část. Nakladatelství C. H. Beck. Praha, 2012.

Herwig, C. H.; Hofmann, C. H. Seven Challenges for EU Administrative Law. Europa Law Publishing. 2009, 2 (2): 37-59.

Kavalnè, S. Administracinès teisès europeizacija - administraciniams teismams aktualūs klausimai. Administraciniai teismai Lietuvo- je. Nūdienos iššūkiai. Lietuvos vyriausiasis administracinis teismas, 2010.

Law on Administrative Procedure of the EuropeanUnion [interaktyvus]. European Added Value Assessment, 2012 [žiūrèta 2013-07-26]. $<$ http://www.europarl.europa.eu/meetdocs/2009_2014/documents/juri/dv/ eav_lawofadminprocedure_/EAV_LawofAdminprocedure_EN.pdf $>$.

Meuwese, A.; Schuurmans, Y.; Voermans, W. Towards a European Administrative Procedure Act. Review of European Administrative Law. 2009, 2 (2): 3-35.

Pomahač, R.; Handrlica, J. Evropské správní právo. Praha: Nakladatelství C. H. Beck, 2012.

Research Network on EU Administrative Law [interaktyvus]. [žiūrèta 2013-07-26]. <http:// www.reneual.eu/>.

Robalino-Orellana, J., et. al. Global Administrative Law. Towards a Lex Administrativa. London: CMP Publishing Ltd., 2010.

Schwarze, J. European Administrative Law. London: Sweet \& Maxwell, 2010.

Schwarze, J. Judicial Review of European Administrative Procedure. Law and Contemporary Problems. 2004: 85-105.

Scott, C. Services of General Interest in EC Law: Matching Values to Regulatory Technique in the Public and Privatized Sectors. European Law Journal. 2000, 6 (4): 310-325.

Seerden, R., et. al. Administrative Law of the European Union, its Member States and the United States: a Comparative Analysis. Oxford: Intersentia Antwerpen, 2007.

State of Play and Future Prospects for EU Administrative Law [interaktyvus]. Working Document of Working Group on EU Administrative Law, 2011 [žiūrèta 2013-07-27]. <http://www.europarl.europa. $\mathrm{eu} /$ document/activities/cont/201210/2012 1025ATT54550/20121025ATT54550EN. pdf $>$. 
Sutartis dèl Europos Sajungos veikimo (suvestinè redakcija). [2010] OL, C 83.

Šedbaras, S. Administracinio proceso teisinio reglamentavimo problemos Lietuvos Respublikoje. Vilnius: Justitia, 2006.

Towards an EU Administrative Procedure Law? [interaktyvus]. Brussels, March $15^{\text {th }}$ $16^{\text {th }}-$ (draft) [žiūrèta 2013-07-23]. <http://
www.reneual.eu/events/ED_conference/ ReNEUAL_conference_March_2012/ Conference $\% 20$ Report $\% 20$ Brussels $\% 20$ March\%2015Th\%20\%2016Th.pdf>.

Valančius, V.; Kavalnè, S. Europos Sajungos teisés igyvendinimas Lietuvos administracinëje teisëje. Vilnius: Registrų centras, 2009.

\title{
THE CONCEPT OF EUROPEAN ADMINISTRATIVE LAW AND THE BACKGROUND OF THE DEVELOPMENT OF THE LAW ON ADMINISTRATIVE PROCEDURE OF THE EUROPEAN UNION
}

\author{
Ieva Deviatnikovaitè \\ Mykolas Romeris University, Lithuania
}

Summary. There are several reasons, according to which it is worth analyzing European administrative law. First, this is a rather new branch of law. Second, the European administrative law is treated in different countries from different legal traditions positions, consequently, any effort to unify the approach to it can provide a basis for a unified European administrative law model. Third, there are no works dedicated to the analysis of the phenomenon of the European administrative law in Lithuania. Therefore, this article deals with the concepts of the European administrative law.

It is stated that the comprehensive image of the European administrative law reveals three European administrative law concepts. The first concept of the European administrative law characterizes it as the European Union (hereinafter - EU) administrative law, the validity of boundaries of which can be based on three aspects - functional, institutional and procedural. The second concept of the European administrative law identifies it as the law of administrative cooperation., whereas the third concept allows the European administrative law to be seen as the law common to various public administrations of European countries ius commune. The article focuses on the analysis of the above-mentioned three approaches and the EU set of administrative procedures as an instrument to promote the development of the EU administrative law.

The author comes to the conclusion that the concept of the 'European Administrative Law' is broader than the concept of the 'EU Administrative Law'. The European administrative law can be perceived not only as a part of law that establishes the EU administration's administrative legal status, its' activity principles, forms and methods, but also as a law of administrative cooperation between states, governmental and non-governmentalorganizations and various corporations, based on a wide range of multilateral treaties or conventions, which cross the limits of the EU. Moreover, the European administrative law can be understood as a law with common concepts, general principles characteristic to different European countries' 
public administrations as well as a science, with the help of which diverse administrative legal systems of various countries could be compared.

Taking into account the content of various working documents, the author draws the conclusion that for the further development of the EU administrative law the establishment of uniform operating rules for the EU administration in its' relations with the society is of exceptional importance. There are a number of important reasons to develop the Law on administrative procedure of the EU. First, it is generally recognized that the EU needs common binding legislation that sets out clear operating rules of the $E U$ administration in its' relations with legal and natural persons, and that would increase the transparency of the EU administration and its' accessibility to citizens. Second, the drafting of the law on administrative procedure of the EU lies in the legal framework as well; the importance of the article 298 of the Treaty of the Functioning of the European Union, the articles 41 and 42 of the Charter of Fundamental Rights of the EU as well as "soft" law (i.e. codes of good administrative behavior) are obvious here.

Keywords: European Administrative Law, the EU Administrative Law, the Law of Administrative Cooperation, Ius Commune, Administrative Procedure of the EU.

Ieva Deviantikovaitė, Mykolo Romerio universiteto Teisès fakulteto Konstitucinès ir administracinès teisès instituto lektorè, socialinių mokslų (teisès krypties) daktarè. Mokslinių tyrimų kryptys: administracinè teisé, lyginamoji administracinè teisè, Europos administracinè teisé, viešojo administravimo institucijos.

Ieva Deviatnikovaitė, Mykolas Romeris University, Faculty of Law, Institute of Constitutional and Administrative Law, Lecturer, Doctor of Social Sciences (Law). Research interests: administrative law, comparative administrative law, European administrative law, public administration bodies. 